\title{
История возникновения и иконография Азовской иконы Божией Матери: опыт изучения малоизвестного образа
}

\begin{abstract}
Аннотащия. В работе осуществлена попытка изучения малоизвестного иконографического образа Азовской Божией Матери, считавшегося безвозвратно утраченным. Предмет исследования - история, иконография, известные списки иконы «Знамение Множества Мира» (Азовская икона Божией Матери). В статье представлен исторический контекст и подлинная история написания и историческая судъба исследуемой иконы, которая окружена множеством мифов и домыслов. На основании архивных материалов, искусствоведческой и богословской литературы и имеюшихся изображений впервые сделан подробный анализ иконографии иконы. В исследовании использованы следующие методы: изучение богословской, исторической и искусствоведческой литературы, работа с архивными и музейными материалами. Научная новизна состоит в том, ито впервые в научный контекст введен подробный анализ иконографии иконы Азовской Божией Матери, а также введено изображение вытегорской иконы, считавщейся безвозвратно утраченной и случайно обнаруженной в краеведческом музее г. Вытегра Вологодской области, впервые осуществлена попытка текстологического анализа надписей, сделанных на исследуемой иконе.
\end{abstract}

Ключевые слова: иконография, Богородичная икона, Азовская икона, прорись иконы, «Киево-Печерский патерик», вытегорская Покровскал иерковъ, гравюры Леонтия Тарасевича, иконографические изображения, князь Голииын, император Петр Алексеевич.

Abstract. The article presents an attempt at studying the little-known iconographic image of the Azov Theotokos, considered to have been irretrievably lost. The research subject is the history, iconography, and known manuscripts of the icon "the Sign of the Multitude of the World" (Azov icon of the Theotokos). The article describes the historical context and true history of the creation and historical fate of the studied icon, which is surrounded by many myths and speculations. On the basis of archival materials, art history and theological literature, and available images the authors conduct the first detailed analysis of the icon's iconography. The research uses the following methodologies: study of theological, historical, art history literature, and examination of archival and museum material. The scientific novelty of the research consists in that this is the first detailed analysis of the Azov Theotokos icon's iconography brought into the scientific context. Furthermore, the authors bring into the scientific art history context the image of the Vytegorskaya icon, considered to have been irreversibly gone but which was accidentally found in the Regional Studies Museum in the city of Vytegra in the Vologoroskaya region. Furthermore, the article for the first time attempts to textologically analyse the inscriptions made on the studied icon.

Key words: iconography, Theotokos icon, Azov icon, icon drawing, "Kiev-Pechersky Patericon", Vytegorskaya Pokrouskaya Church, Leontiy Tarasevich engravings, iconographic images, prince Golitsyn, emperor Peter Alexeyevich.

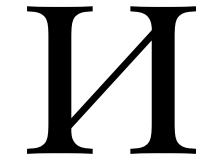

зучая типы Богородичных икон, мы встретили необычный образ - Азовскую икону Божьей Матери. В «Православной энциклопедии» [1, с. 337] мы нашли об этой иконе лишь небольшую статью. Когда мы начали искать другие источники, мы поняли, что существует несколько отличающихся списков этой иконы, а история создания запутана. Г.Б. Арутюнов писал: «Икона «Знамение Множества Мира» (Азовская икона Божией Матери) - одна из самых таинственных и загадочных икон в истории русского православия. Сведения об этой иконе в литературе противоречивы и не полны, а то и вовсе отсутствуют. Её обретение полно загадок и недомолвок» [2]. Какова же подлинная история иконы? Какова её 


\section{Исторический журнал: научные исследования № 3 (33) • 2016}

DOI: $10.7256 / 2222-1972.2016 .3 .19489$

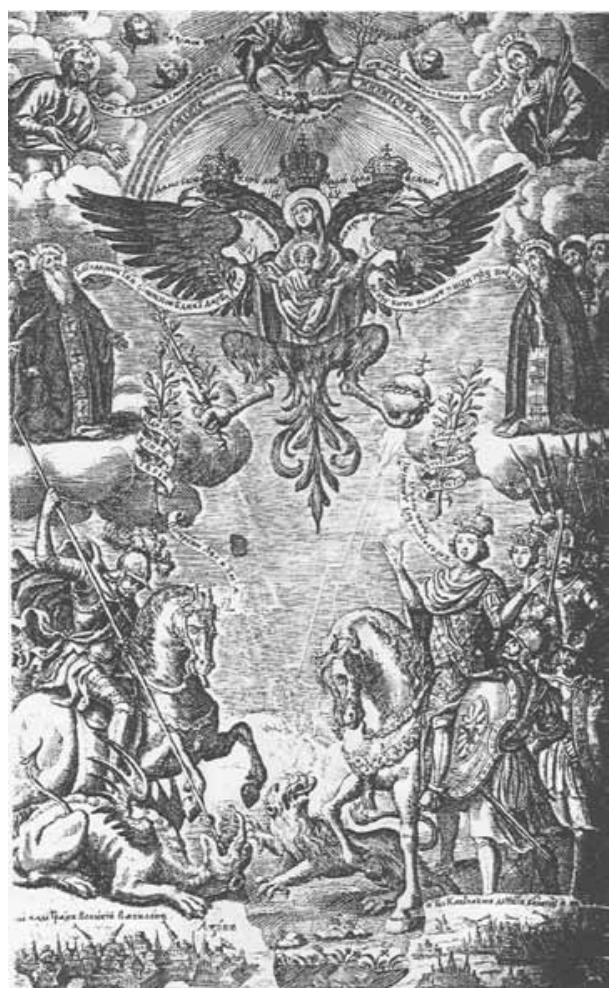

Рис. 1. Фронтиспис Киево-Печерского патерика, 1702 г.

иконография? Почему списки этой иконы существенно отличаются друг от друга? Эти вопросы побудили начать серьёзное исследование, объектом которого и стала икона «Знамение Множества Мира» (Азовская икона Божией Матери), а предметом - история её возникновения, иконография и известные списки.

\section{1. История возникновения иконы 1.1. Ахтырская прорись}

Новое издание «Православной энциклопедии» [1, с. 337] утверждает, что иконография Азовской иконы Божьей Матери (XVII век) восходит к прориси для гравюры, выполненной по поручению дьяка Федора Шакловитого Данилой и Яковом Перекрестовыми и вырезанной на меди «черкашенином Тарасовичем», в Ахтырке (подмосковном имении князя Василия Васильевича Голицына).

В декабре 1702 г. в типографии Киево-Печерской лавры был издан Патерик с посвящением Петру I. Фронтиспис к изданию 1702 г. (см. рис. 1) был гравирован графиком Леонтием Тарасевичем (1650(?)-1710(?)). Известен иной вариант этой гравюры того же автора. Его

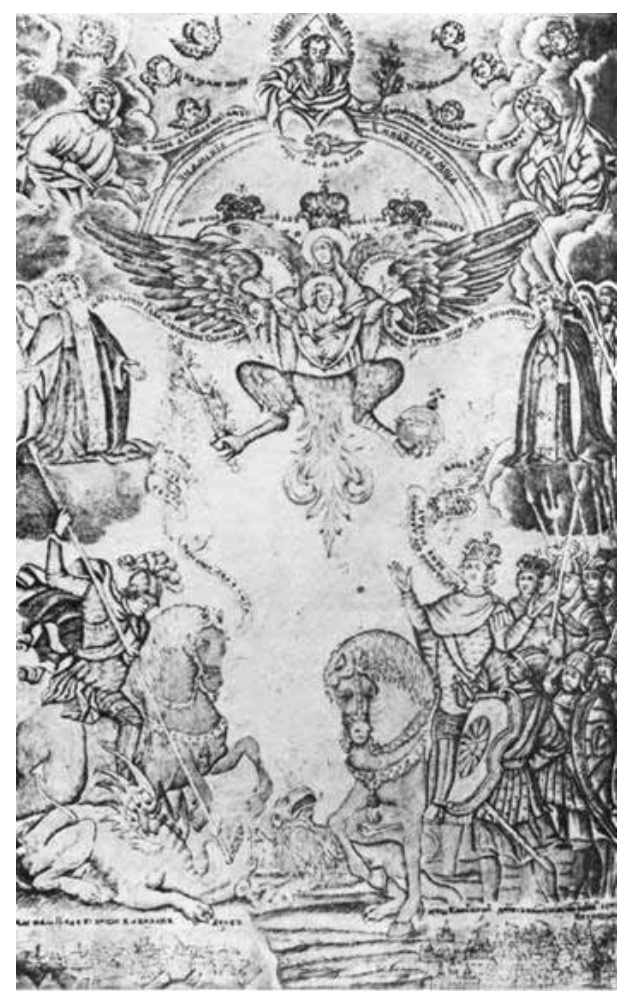

Рис.2. Фронтиспис Киево-Печерского патерика, 1768 г.

приводит М.М. Красилин [3, с. 162, прил. 37] (см. рис. 2).

История возникновения Азовской иконы связана с русско-турецкими войнами, с утверждением России на побережье Чёрного и Азовского море.

Наиболее подробно исследовал икону Азовской Божией Матери «Знамение Множества Мира» дореволюционный искусствовед и архитектор Василий Михеевич Борин (1863-?). Все современные исследователи (включая составителей «Православной энциклопедии») ссылаются, в основном, на публикацию В.М. Борина [4]. Он считает, что почитание иконы начинается при царице Софии Алексеевне (1657-1704) со времени первого похода к Азову в 1686 г. под предводительством кн. В.В. Голицына. Иконография восходит к прориси для гравюры, выполненной в XVII веке.

«Исследуя икону, я нахожу на ней до трёх записей; из-под них видно, что первоначальное изображение Богоматери было «поясное», а не «ростовое»; из этого можно заключить, что к этой иконе Азовской Божией Матери возвращались, когда возвращался политический интерес к Азову. И только во второй половине 
XVIII века... образ, надо полагать, остаётся уже без всякого изменения, так что икона в том виде, в каком её находим, относится к концу XVIII века, ко времени Императрицы Екатерины II (1763-1796). Причём, можно утвердительно сказать, как прорись, так и икона, хранящиеся в Историческом музее, являются единственными экземплярами, оставшимися от конца XVII века» [4]. В.М. Борин пишет это в 1914 году. К сожалению, в настоящее время местонахождение прориси неизвестно.

Итак, начнём по порядку. Вот что в этой же статье пишет В.М. Борин о прориси: «История этого памятника, любопытна и соединена с именем и судьбой царевны Софьи Алексеевны. Прорись сначала была составлена по поручению Федора Шакловитого «вещанием Даниила и Якова Ивановых, детей Перекрестовых», «назнаменована она была на большом листе» в Ахтырке, подмосковном имении князя Василия Васильевича Голицына в доме стрелецкого полковника Ивана Перекрестова, и надо полагать, по случаю возвращения «царского оберегателя», князя Голицына из первого Крымского Азовского похода, совершенного в 1686 году, в котором участвовал гетман Самойлович с запорожским войском. Крымские походы в Москве признали очень важным, по крайней мере друзья Голицына и в особенности правительница, царевна София. За эти походы кн. Голицын был не забыт царями, что было отмечено данной ему грамотой, где особенно указывалось на важность достигнутого мира: «Мы, великие государи, говорилось в грамоте, тебе, ближнего нашего боярина и оберегателя, за твою к нам многую и радетельную службу, что такие свирепые и исконные (враги) Креста Святого и всего христианства неприятели твоею службою не нечаянно и никогда не слыханно от наших царских ратей в жилищах их поганских поражены и побеждены и прогнаны, и что объявились они сами своим жилищам разорителями: отложа свою свирепую дерзость пришед в отчаяние и в ужас, в Перекопи посады и села и деревни всё погоша, и из Перекопии с своими поганскими ордами тебе не показались и возвращающимся нам не явились, и что ты со всеми ратными людьми к нашим границам с вписанными славными во всем свете победами возвратились в целости, милостиво и премилостиво похваляем». Прорись доступными ей средствами выразила тот «зело радостный день, по выражению царевны Софии, что Господь Бог прославил им Свое
Святое, также и Матери Своея Пресвятыя Богородицы, по предстательству Святых угодников Божиих и преподобного Сергия чудотворца милостивого. Чего от века не слыхано, ни отцы наша поведаша нам такого милосердия Божия. Слава Богу нашему, даровавшему мир и помиловавшему нас, через тебя, Батюшка мой!» [4].

Таким образом, современники Голицына в Крымских походах видели великий подвиг, великую победу над «исконными неприятелями всего христианства», изображенными в виде крылатого дракона и льва великого.

Следовательно, прорись Исторического музея была аллегорией, изображающей одно из знаменательных событий нашей истории конца VII века. С этой «назнаменованной» прориси была вырезана гравюра на меди, в Ахтырке, «черкашенином Тарасевичем» по заказу Шакловитаго. Гравюра эта была поднесена сыновьями Перекрестова в 1688 году с отцом в Москве, где она на Белгородском подворье и печаталась на атласе, тафте и бумаге. От этих последних гравюр не осталось ни одного экземпляра.

В.М. Борин, ссылаясь в своей работе на исследование Д.А. Ровинского, сообщает о судьбе гравюры следующее: «Пётр, стремясь удержать вырванную у Софьи власть, уничтожал не только фаворитов царицы (Шакловитого, Галицына), но и всё, что было связано с ней. Исследователь XIX века по иконографии Д.А. Ровинский пишет: «В последствии оттиски этого портрета по приказанию Петра 1-го, отбирались так исправно, что до нас не дошли из них ни одного экземпляра» [3]. Выше мы сообщали, что не известно в настоящее время и местонахождение прориси, до революции 1917 года хранящейся в Историческом музее.

Опираясь на вышесказанное, можно сделать вывод, что В.М. Борин описывает не оригинальную икону, а её список, относящийся к концу XVIII века, который и хранился в Историческом музее до революции, но его местонахождение сегодня не известно. При этом исторический аспект описан довольно точно.

Б.Н. Кузык, опираясь на исследование В.М. Борина, указывает [5, с. 291-292], что гравюра была преподнесена в 1688 году и вырезана по прориси, написанной после второго Крымского похода князя В.В. Голицына 1689 года и окончательного замирения с крымским ханом Нурадином. Здесь явная нестыковка дат и это требует дополнительного исследования. 


\section{Исторический журнал: научные исследования № 3 (33) • 2016}

DOI: $10.7256 / 2222-1972.2016 .3 .19489$

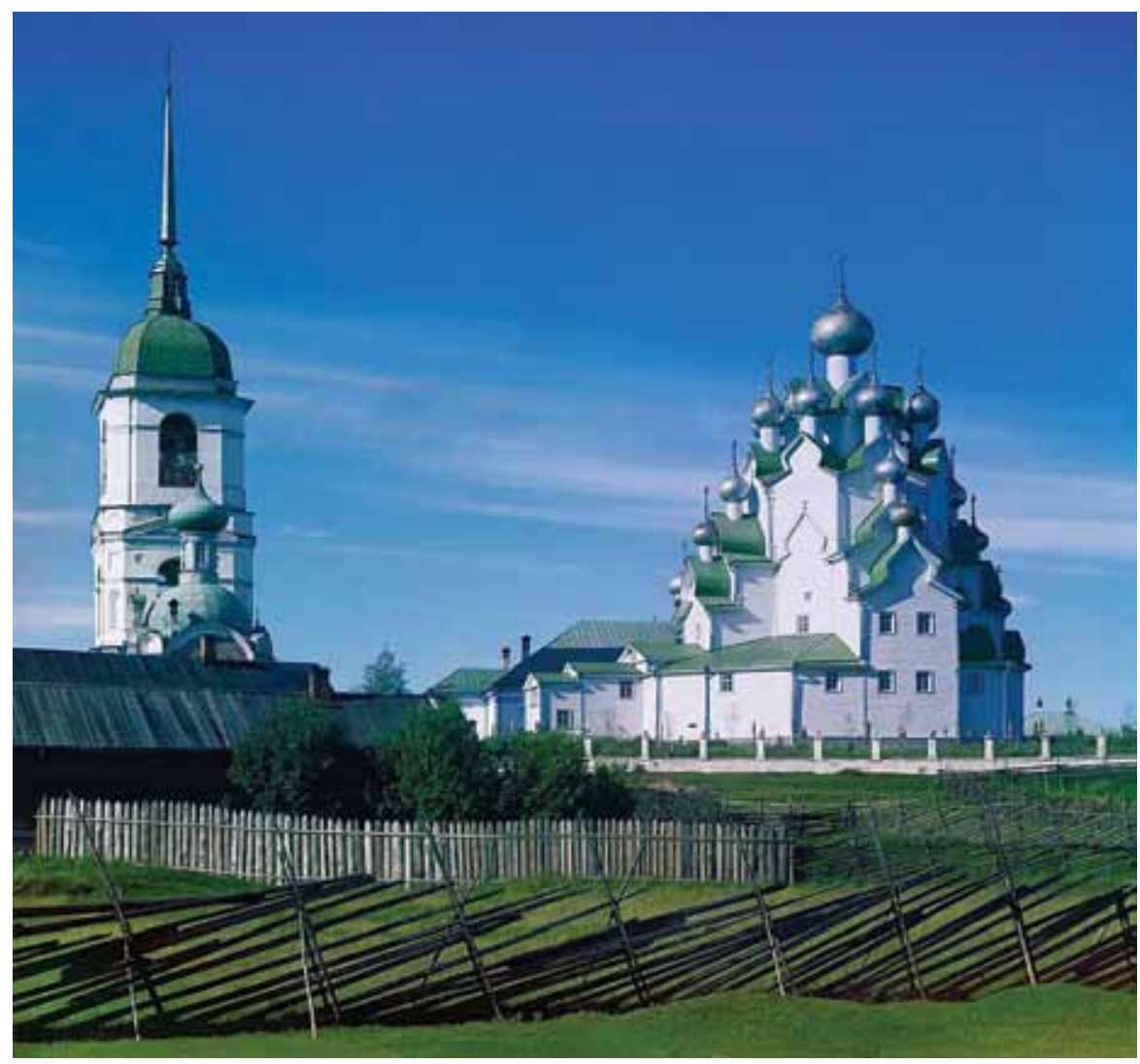

Рис. 3. Покровская церковь в Вытегорском Погосте. Фото 1909 года С.М. Прокудина-Горского

\section{2. Вытегорская икона Божией Матери Азовской: история возникновения}

Подробную историю возникновения первой иконы Азовской Божией Матери и её полное описание приводит в «Олонецких губернских ведомостях» священник Спиридон Партанский (1826-?), с 31 декабря 1870 года 20 лет служивший в Покровской церкви Вытегорского Погоста. Имеется краткое жизнеописание священника Спиридона Партанского [6].

В начале он приводит подробное описание деревянной Покровской церкви, которая располагалась в селе Анхимово (Вытегорский Погост). «Вытегорская Покровская церковь, и по наружному своему виду, и по времени построения, есть замечательный христианский памятник Петровской старины в Вытегорском уезде. Народное предание говорит, что она построена по плану и рисунку Петра I» [7, с. 8(212)] (Поскольку газета выходила со сплошной нумерацией в году страниц, здесь и далее в скобках указан этот номер сплошной нумерации).
Сохранилась фотография (рис. 3 [8]) этой сгоревшей в 1963 году церкви [9, с. 24], сделанная 1 января 1909 году пионером цветной фотографии в России Сергеем Михайловичем Прокудиным-Горским, вошедшая в его знаменитую «Коллекцию достопримечательностей Российской империи».

Художник А.А. Рыбаков пишет, что «Церковь эта деревянная, обшита тёсом и выбелена мелом. В основании своём имеет четырёхконечный крест, который к верху украшен 20 главами <...> Народное предание говорит, что она построена по рисунку Петра I и об этом рассказывают следующее: «В царствование Петра I, в Вытегорском погосте, в деревне Крюковой, жил один очень богатый крестьянин, по прозванию Плотников. <...> Сын богача Плотникова подпал опале Государя и был по Его повелению казнён. $<\ldots>$ Убитый горем и, не зная кому оставить своё богатство, Плотников ещё до выезда Государя вздумал построить в память казнённого сына над его могилою богатую церковь, в которой бы приносилась о нём бескровная жертва, и кряду 


\section{Культурное наследие - памятники истории и культуры}

обратился с просьбою - разрешить привести в исполнение задуманную им мысль. Пётр на этот раз внял просьбе и Сам тут же начертил рисунок, по которому впоследствии и воздвигнута эта церковь». Далее народное предание прибавляет, что Пётр на этот раз останавливался в доме местного священника, который в память этого посещения написал аллегорическую икону: Знамение множества мира» [7, с. 8-9(212-213)]. Автор этого очерка указывает, что это предание было им записано в 1871 году со слов слепого священника Стефана Смирнова и в том же виде оно передавалось и местными жителями» [10].

На иконе Знамения множества мира, которая в описываемые о. Спиридоном времена находилась в каменной церкви в приделе Казанской Божией Матери против главного клироса имеется надпись «1729 года, марта, в 30 день, писал сей образ поп Климент Макарьев». Кроме того о. Спиридон сообщает, что «как видно, она недавно ещё поновлена» [7, с. 8(212)].

Существуют версии, что икона была написана ранее 1729 года, так как при реставрации цифры, которые обозначаются церковнославянскими буквами, могли по небрежности или невнимательности заменить на похожие по написанию. На наш взгляд, церковно-славянскую надпись «* $1 \overrightarrow{\mathrm{K}} \overrightarrow{\theta_{t}}$ (1729) значительно легче перепутать с «х $х \vec{\varphi} \overrightarrow{\theta_{1} »(1699), ~ ч е м ~ с ~ « ~}$ она короче на целую букву) или «夫 поэтому предположение отца Спиридона Партанского о том, что икона может датироваться 1699 годом вполне правдоподобна. Но утверждать, что икона написана ранее 1729 года мы не можем за неимением фактов, подтверждающих это.

\section{3. Оригинал иконы существует...}

До недавнего времени считалось, что икона «Знамение множества мира» сгорела вместе с Покровским храмом в 1963 году. И только весной 2014 года на сайте Вытегорского музея мы случайно увидели фотографию одного из залов музея, на которой была икона, схожая по описанию с иконой «Знамение множества мира» Азовской. По нашей просьбе директор музея прислала нам фотографию этой иконы (рис. 4) и только тогда стало ясно, что это та самая Азовская икона, ибо изображение в деталях совпало с имеющимися описаниями XVIII века. Икона была перенесена в музей до того, как случился пожар, благодаря чему мы сегодня

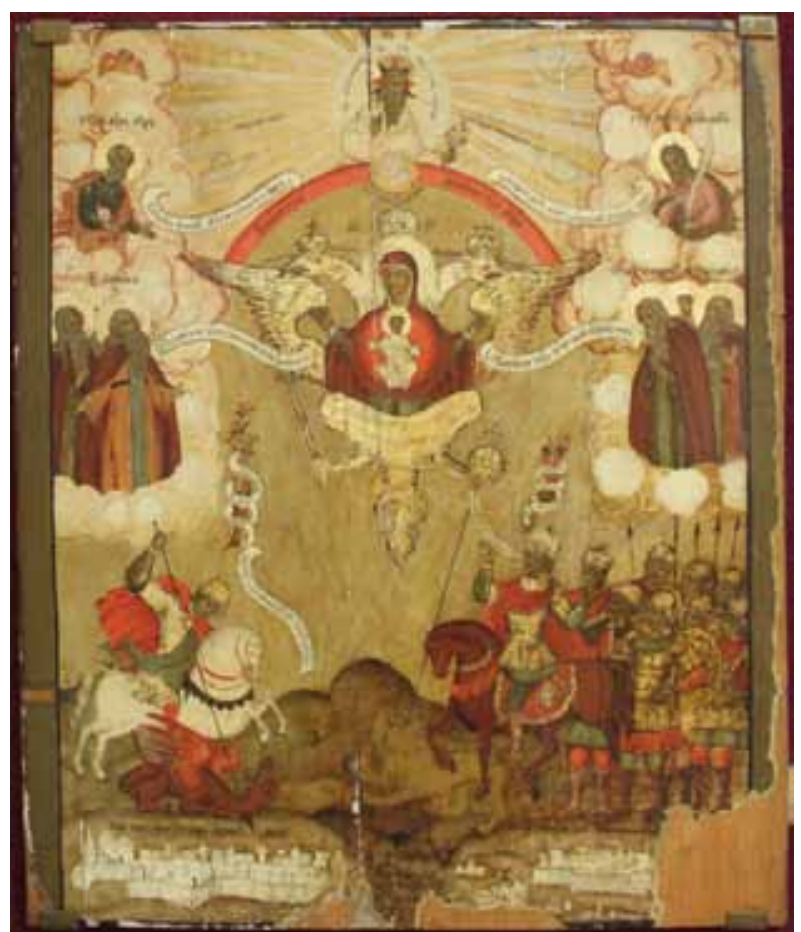

Рис. 4. Икона Божией Матери Азовская «Знамение множества мира».

Вытегорский краеведческий музей. Фото 2014 года. Публикуется впервые.

можем наблюдать этот памятник культуры XVII-XVIII века почти без повреждений и изменений. Ни в одном источнике оригинал иконы не публикуется, поэтому тот факт, что оригинал сохранился - открытие не только для нас, но и для всего научного мира.

Таким образом, изучив и проанализировав исторические и архивные материалы, исходя из всего вышесказанного, можно сделать вывод, что Азовская икона Божией Матери была написана по гравюре Леонтия Тарасевича, а если эта гравюра была напечатана в 1702 году, то, следовательно можно утверждать, что икона была написана в период с 1702 по 1729 годы.

\section{2. Иконография}

\section{1. Общее описание}

Существуют различные варианты описаний Азовской иконы. Наиболее ранее из них мы находим в тех же «Олонецких губернских ведомостях». В 1860 году был опубликован очерк «Окрестности города Вытегры» [11]. Константина Михайловича Петрова (1836-?), который согласно энциклопедии Брокгауза-Ефрона «был преподавателем и инспектором народных учи- 


\section{Исторический журнал: научные исследования № 3 (33) • 2016}

DOI: 10.7256/2222-1972.2016.3.19489

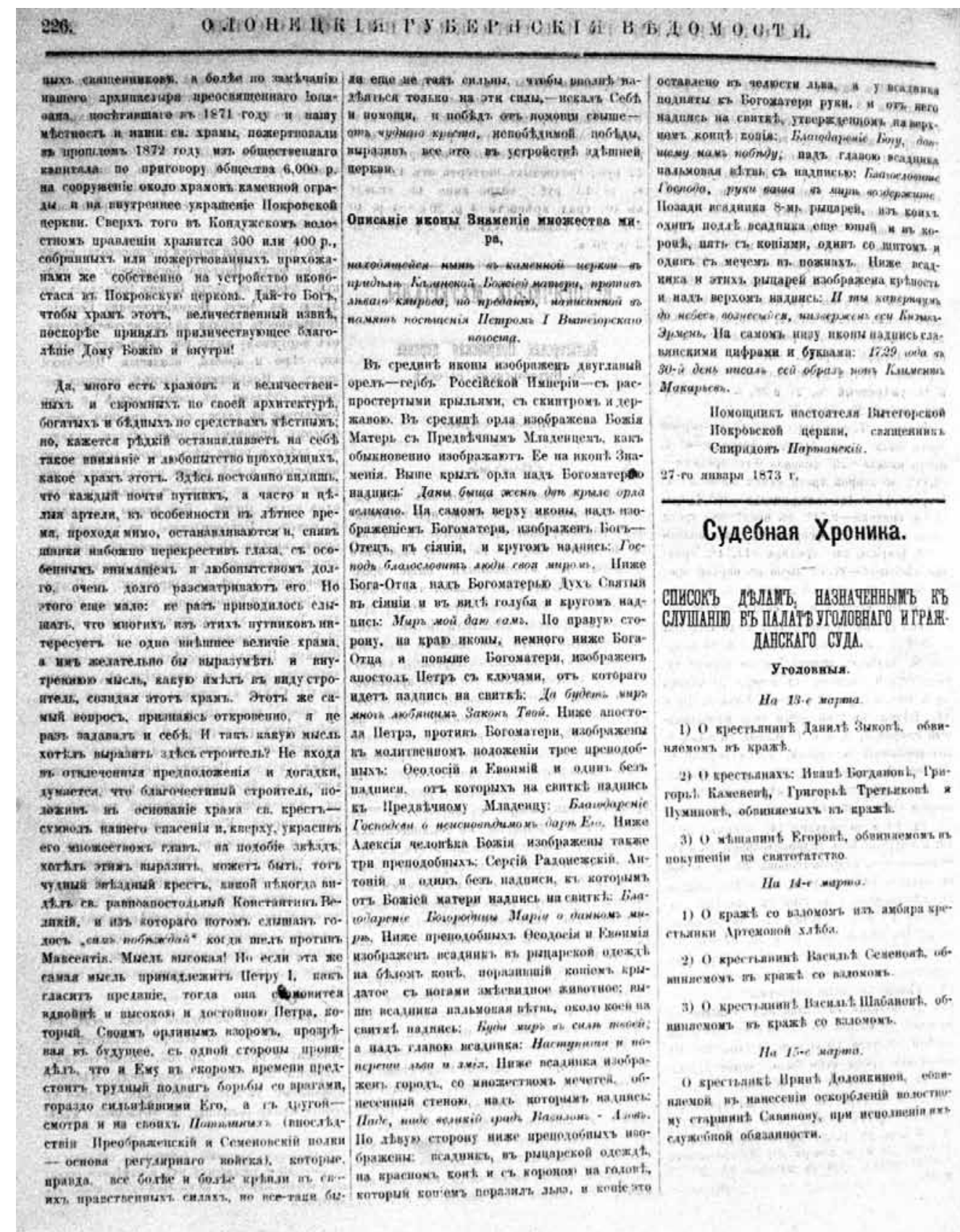

Рис. 5. Страница «Олонецких губернских ведомостей» с описанием иконы «Знамение множества мира» (1873 г.)

лищ, а также почетным мировым судьей» [12] в Олонецкой губернии и был известен как автор «Краткого описания Олонецкой губернии» (Петрозаводск, 1881). В этом очерке подробно приводится описание исследуемой нами иконы. Вот что пишет он о ней: «Вверху изображенъ Господь Саваофъ и вокругъ его слова: «Господъ благослови люди своя миромб», съ боковъ - «на землг мирв въ человъ иъъх благовольніе»<.> Далъе - спра- ва: «благодать и мирв да умножатся имъ»; съ льва: «да будетв мирг многъ любящимг законъ его». За симъ по срединъ: «знаменіе множества мира», а по бокамъ изображенія Св. Апостола Петра и Алексія человька Божія. Ниже - въ срединъ Россійскій двухглавый орелъ съ распущенными крыльями и съ надписью на нихъ: «даны быша женґ два крыла орла великаго». На орль возсьдаетъ Матерь Божія; внизу орла надписи съ боковъ: 
«благодареніе Господеви о ниспосланномъ дарг его» и «благодареніе Богородичъ Маріґ о данномъ намъ миргъ. Далье справа - изображенія Св. Евөимія и Антонія Печерскаго и надпись: «буди миръ въ силь твоей»; сльва - Сергій Радонежскій и Өеодосій Печерскій и надпись: «и благословить Господь руки ваша въ мирг воздержанія». Подъ изображеніями Св. Угодниковъ, на правой сторонъ надпись: «наступиши и попереши льва и змія», а подъ нею ангелъ на конъ, поражающій діавола; на львой сторонъ слова: «благодареніе Господу, давшему намъ побгду» и подъ ними воины п шіе и конные. Подъ ангеломъ изображенъ разрушенный городъ, съ надписью: «паде, паде великій градъ Вавилонг Азовъ»; подъ воинами то же городъ и слова: «и ты Капернаумг до небеси возвысился, низверженг еси Кизикъ Арменъ». Въ заключеніе на краю иконы подписано: «1729 года Марта въ 30 день писалъ сей образъ попъ Климентъ Макарьевъ».

Схожее описание Азовской иконы приводит в 1873 году священник Спиридон Партанский (рис. 5). «В середине иконы изображён двуглавый орёл - герб Российской империи - c рапростёртыми крыльями, с скиптром и державою. В середине орла изображена Божия Матерь с Предвечным Младенцем, как обыкновенно изображают Её на иконе Знамения. Выше крыл орла над Богоматерью надпись: Даны быща жен дв крыле орла великаго. На самом верху иконы, над изображением Богоматери, изображён Бог-Отец, в сиянии, и кругом надпись: Господь благословитв люди своя миромб. Ниже Бога-Отца над Богоматерью Дух Святый в сиянии и в виде голубя и кругом надпись: Мирг мой даю вамг. По правую сторону, на краю иконы, немного ниже Бога-Отца и повыше Богоматери, изображён апостол Пётр с ключами, от которого идёт надпись на свитке: Да будетв мирг многъ любящимъ Законв Твой. Ниже апостола Петра, против Богоматери, изображены в молитвенном положении трое преподобных: Феодосий и Евфимий и один без надписи, от которых на свитке надпись к Предвечному Младенцу: Благодареніе Господеви о неиспов димомг дар Его. Ниже Алексия человека Божия изображены также три преподобных: Сергий Радонежский, Антоний и один без надписи, к которым от Божией Матери надпись на свитке: Благодареніе Богородищъ Маріи о данномъ мир. Ниже преподобных Феодосия и Евфимия изображён всадник в рыцарской одежде на белом коне, поразивший копием крылатое с ногами змеевидное животное; выше всадника пальмовая ветвь, около коей на свитке надпись:
Буди мирг вг сил твоей; а над головой всадника: Наступиши и попереши льва и змія. Ниже всадника изображён город с множеством мечетей, обнесённый стеною, на которым надпись: Паде, naдe великій градъ Вавилонг - Азовъ. По левую сторону ниже преподобных изображены: всадник, в рыцарской одежде, на красном коне и с короною на голове, который копием поразил льва, и копие это оставлено в челюсти льва, а у всадника подняты к Богоматери руки, и от него надпись на свитке, утверждённом на верхнем конце копия: Благодареніе Богу, дающему намг побъду; над главою всадника пальмовая ветвь с надписью: Благословите Господа, руки ваша в мирг воздержите. Позади всадника 8-мь рыцарей, из коих один подле всадника ещё юный и в короне, пять с копиями, один со щитом и один мечём в ножнах. Ниже всадника и этих рыцарей изображена крепость и над верхом надпись: И ть капернаумб до небесъ вознесыйся, низверженб еси Кизыкъ-Эрменъ. На самом низу иконы надпись славянским цифрами и буквами: 1729 года в 30-й денъ писалв сей образ попъ Климентв Макаръевъ» [7, с. 12(226)].

Священник Спиридон Партанский, описывая икону, ориентируется не на восприятие смотрящего, а на расположение Богородицы. Когда он указывает «справа» или «слева», то следует понимать как «по правую или левую руку Богородицы».

\section{2. Лики}

На иконе помимо Богоматери с Младенцем изображён Господь Саваоф, Святой Дух в виде голубя и ряд фигур святых и воинов. Попробуем разобраться, кто они и какая связь между ними.

Принципиально то, что на иконе изображена Ветхозаветная Троица, что является нарушением канонов иконографии. Бог-Отец изображен в виде старца с веткой какого-то растения в левой руке, а правой как бы благословляет мир, Бог-Сын сидит на коленях у Богородицы с распростёртыми руками, а Святой Дух изображён традиционно в виде голубя и расположен ниже Господа Саваофа над головой Богоматери.

Изображение Богородицы расположено на фоне двуглавого орла - символа державности России. На иконе можно заметить удивительную закономерность: как у двуглавого орла распростерты крылья над миром, так и у Богоматери, и у Младенца Иисуса распростерты руки над землёй. Можно предположить, что это симво- 


\section{Исторический журнал: научные исследования № 3 (33) • 2016}

\section{DOI: $10.7256 / 2222-1972.2016 .3 .19489$}

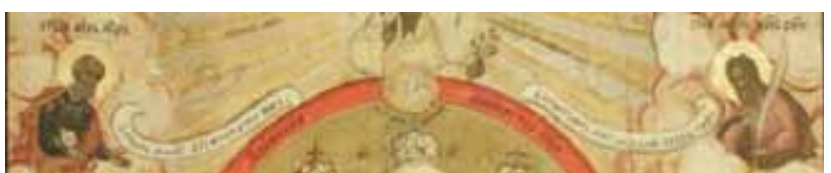

Pис. 6.

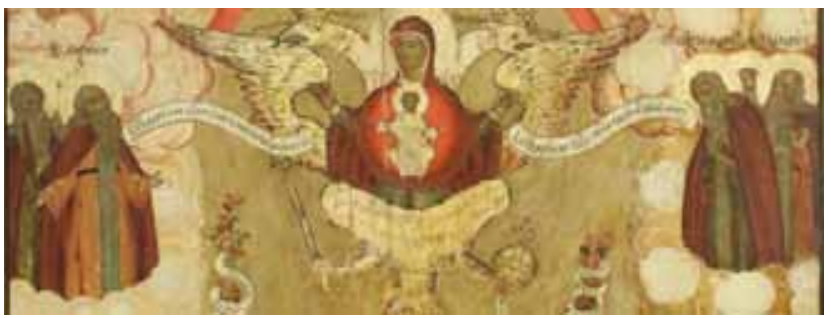

Puc. 7.
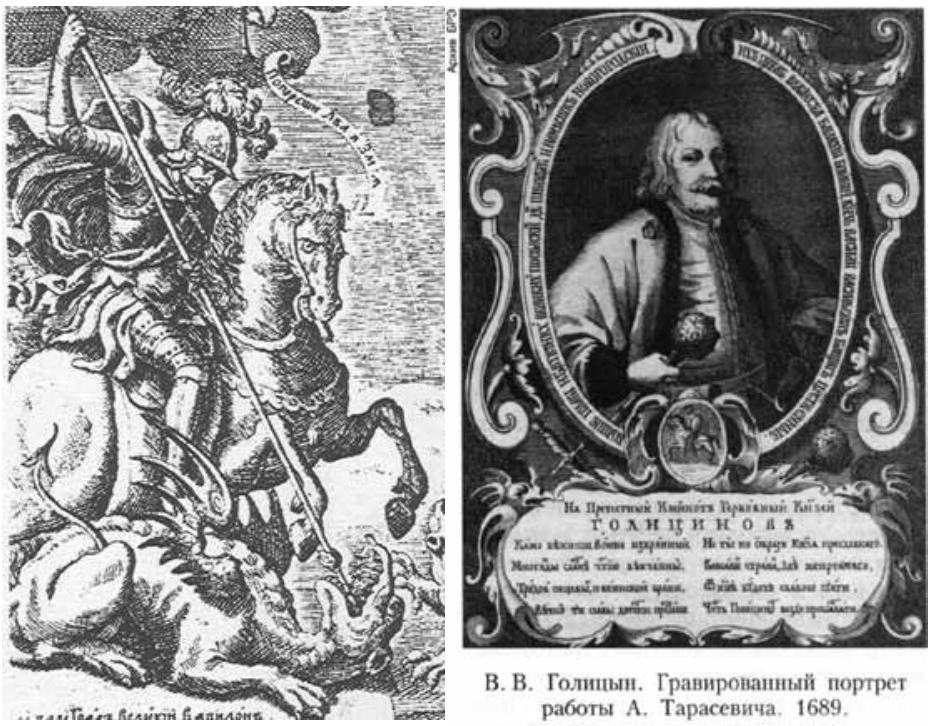

В. В. Голишын. Гравированный портрет работы А. Тарасевича. 1689.

Рис. 9.

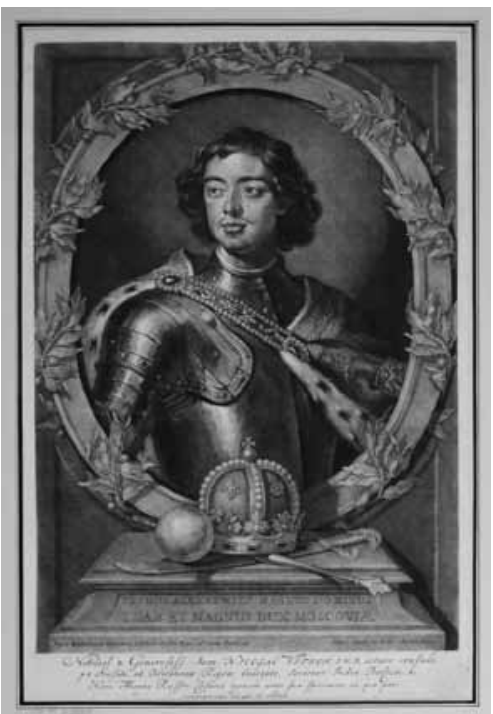

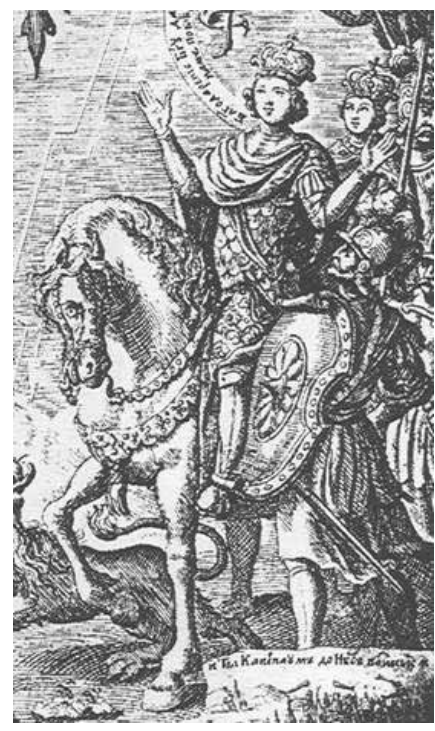

Pис. 10.

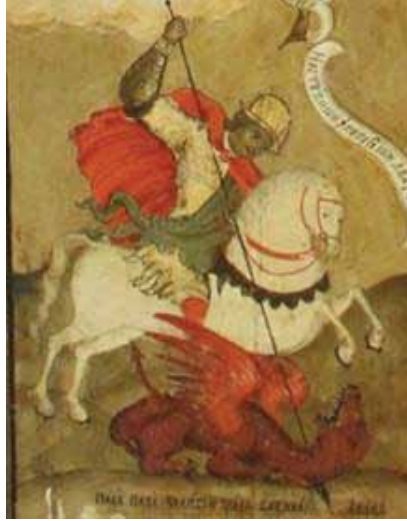

Рис. 8.

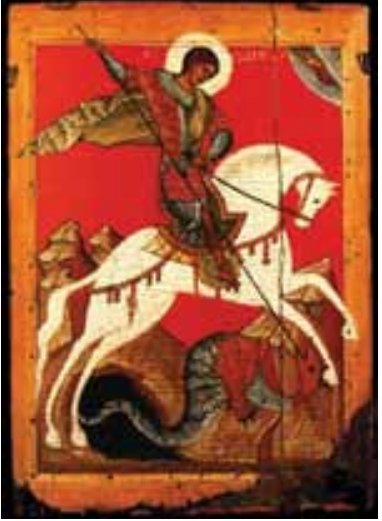

$\sigma$

лизирует Божье покровительство над Россией. Случайное ли это совпадение или намеренный ход иконописца, нам остаётся только догадываться.

Икона как бы условно поделена на две части: первые два ряда - Царство Небесное, здесь в облаках изображены Святая Троица, Богородица и святые покровители Русской земли, ниже - царство земное.

В первом ряду мы видим изображения св. Апостола Петра (слева) и св. Алексия Человека Божия (справа) (рис. 6). Они изображены не случайно, ведь Апостол Петр - небесный покровитель Петра I, св. Алексий - цесаревича Алексия (1690-1718). Существуют версии, что первоначально на прориси к иконе был изображен не св. Алексий Человек Божий, а св. Иоанн Предтеча. «По сторонам Господа Саваофа - Святые, соименитые царям Петру и Иоанну: Св. апост. Пётр с ключами в руках и Св. Иоанн Предтеча», - пишет В.М. Борин [4]. Таким образом, можно предположить, что прорись была сделана до рождения цесаревича Алексея, то есть до 1690 года, но так как прорись иконы не сохранилась, у нас не достаточно фактов, чтобы утверждать, что на прориси был изображен Иоанн Предтеча - небесный покровитель Иоанна V Алексеевича.

Во втором ряду под изображениями св. Апостола Петра и св. Алексия Человека Божьего расположены святые: справа преподобные Сергий Радонежский и Феодосий Печерский, слева Св. Евфимий и Антоний Печерский 
(рис. 7). Также по обеим сторонам изображены святые без подписи, и нам остаётся только догадываться, кто это может быть. Объяснение, почему на иконе изображены именно эти святые, не найдено и это ещё предстоит исследовать.

Третий ряд - это уже царство земное. Слева мы видим всадника на белом коне, поражающего копьём крылатое чудовище (рис. 8a). Внешне этот всадник очень напоминает св. Георгия Победоносца (рис. 8б). Утверждать, что это изображение св. Георгия Победоносца мы не можем, так как над головой всадника нет изображения нимба.

В.М. Борин находит [4] во всаднике портретное сходство с князем В.В. Голицыным, который был предводителем Азовских походов. Сравним вышеупомянутую гравюру Л. Тарасевича с его же портретной гравюрой князя В.В. Голицына [13] (рис. 9).

Трудно не согласится с В.М. Бориным, тем более, что гравюры выполнены одним автором.

С правой стороны изображены «два всадника на конях, надо полагать, Пётр и Иоанн, в характере Св. муч. Бориса и Глеба, но также без надписей и нимбов» [4], зато в царских коронах с крестами. Первый всадник на гравюре Л. Тарасевича имеет явное сходство с Петром I, особенно с гравюрой 1697 года работы П. Шенка [14] (рис. 10). Изображенные на обеих гравюрах одинаковые царские короны подтверждают мысль, высказанную В.М. Бориным.

Однако утверждать, что второй всадник это Иоанн, мы не можем, так как существует мнение [15], что это царевич Алексей.

\section{3. Символика иконы}

Исследуемая нами икона отличается не только композиционными особенностями, но и необычной, порой загадочной символикой. Каждый из исследователей этой иконы по-своему толковал определённые символы. Мы попробуем разобраться в этом.

В.М. Борин приводит толкование образов на гравюре Азовской иконы: «На это изображение было сделано толкование для царевны Софьи Александровны иеромонахом Московского Новоспасского монастыря Инокентием (в последствии митрополитом Тобольским): «Это изображение, поясняет иеромонах, знаменует Софью, сиречь Премудрость Божию, которая с Апостолом Петром и Крестителем Иоанном охраняют Российское Государство. Также с двумя братьями Петром и Иоанном восседает на престоле Государства Российского исполнены благим попечением о нём. Два крыла орла означают двух теток: Анну Михайловну и Татьяну Михайловну, при помощи их молитв, как бы при помощи крыльев, те благоволили царевне Софье, управлять Государством Российским. Благославляющий Господь Саваоф означает, что Сын Божий исполнен премудрости, а премудрость Ветхого и Нового Завета - Божественной церкви основание, мученеческая кровь и апостольская проповедь - пророческое Божественное учение. Христос камень веры, камень его же небрегоша зиждущии сей бысть во главу угла, на этом камне создав церковь Свою. Глава церкви Христос»» (орфография авторская, без изменений).

Из этого толкования можно сделать вывод, что первоначально на гравюре вместо св. Алексия Человека Божьего был изображен св. Иоанн Креститель, а значит гравюры Л. Тарасевича, которые мы имеем, - это более поздние копии с оригинала. Но вернёмся к иконе.

Итак, как мы уже сказали, на иконе изображение Ветхозаветной Троицы. Бог-Отец находится над всеми, и с высоты смотрит на мир (рис. 11). Правой рукой Он осеняет землю крестным знамением, а в левой руке держит то ли ветку какого-то растения, то ли красные цветы. Что это за растение и почему оно изображено на иконе, пока остаётся для нас загадкой и требует дополнительного изучения. От Господа Саваофа исходят, как от солнца, лучи. В.М. Борин пишет: «от Него исходят семь лучей, достигающих главы Богоматери, означающих семь даров Духа Святого: Премудрость, Разум, Совет, Крепость, Ведение, Благочестие, Страх Божий; или же: Веру, Надежду, Любовь, Чистоту, Смирение, Благодать и Славу Божию» [4]. На иконе же мы видим, что лучей больше, чем семь. Видимо, В.М. Борин, описывая икону, имел в виду лучи, которые изображены на нимбе.

Спустимся взглядом ниже. Под изображением Бога-Отца мы видим красный полукруг (рис. 12). Исследователи отмечают, что этот полукруг - радуга, и на более поздних списках его пишут разными цветами. (рис. 13).

Такое толкование вполне обоснованно, а надпись «Знамение множества мира» на полукруге вполне подтверждает это.

Ниже под радугой изображена Богородица на фоне двуглавого орла со скипетром и державой в лапах - символами государственности. Вот что пишет об этом В.М. Борин: «как видно 


\section{Исторический журнал: научные исследования № 3 (33) • 2016}

DOI: $10.7256 / 2222-1972.2016 .3 .19489$

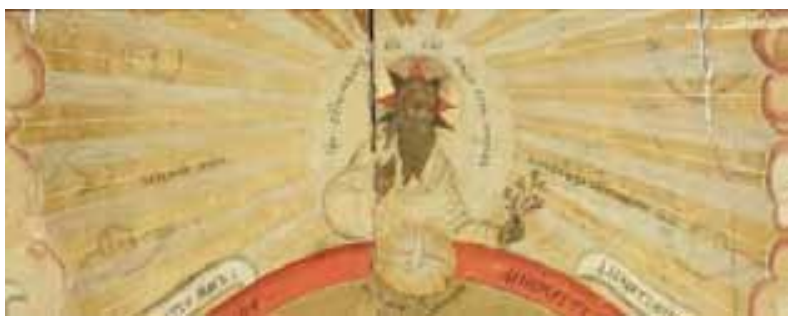

Рис. 11.

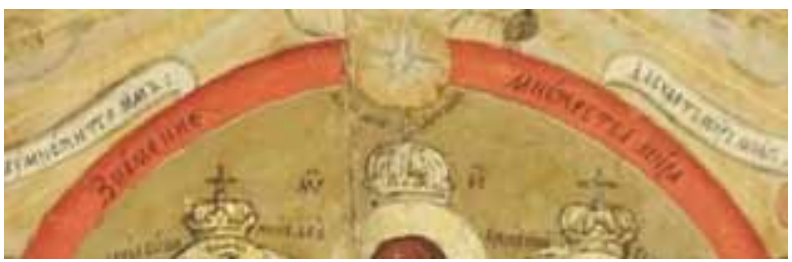

Рис. 12.

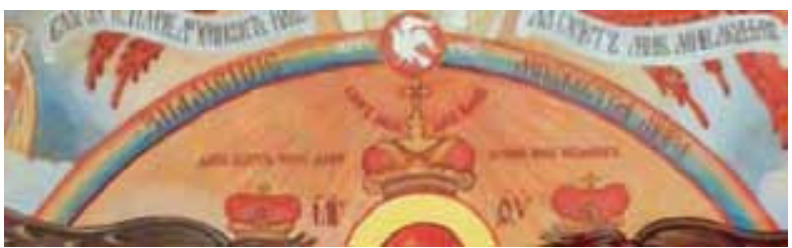

Рис. 13.

из «дела о Фёдоре Шакловитом и его сообщниках», было изображено: вверху Бог Отец и Святой Дух в виде голубином, от Коего исходят семь лучей, достигающих до главы Богоматери, означающих семь даров Духа Святого <...>. По сторонам Господа Саваофа - Святые, соименитые царям Петру и Иоанну <...>, а ниже - София Премудрость Божия: Богоматерь с воздетыми вверх руками (оранта) и с Младенцем Христом в «орле»» [4]. Как уже сказано выше, крылья орла символизируют двух теток Софьи, которые помогали царевне управлять государством.

«Несколько ниже, с каждой стороны, изображены ветви лавра, символов мира, перевитые лентами с надписями на них, на левой - «Буди мир велий Твой», а на правой - «Воздежите руци ваши» [4].

Внизу на иконе изображены всадники, поражающие копьями льва и змия (рис 14). В.М. Борин отмечает что, «здесь выражено иносказательно поражение Турок и Татар, а может быть указание на попрание личности врага Голицына Льва Кирилловича Нарышкина» [4]. Существует и другое мнение о значении этих животных. В работе Елены Погосян и Марии Сморжевских мы находим такое толкование: «Змей представляет на иконе Турцию, лев - Швецию, войну с которой Петр объявил на следующий день по заключении мира с Портой (1700г.)» [15]. Ка-

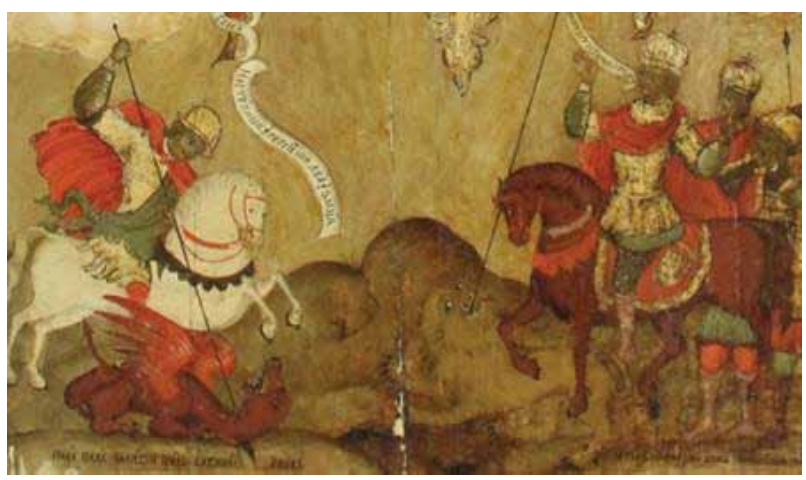

Рис. 14.

кой из этих вариантов толкований вернее, мы не знаем, но оба они вполне обоснованы.

Под изображениями всадников расположены схематичные, характерные для иконографии, города-крепости: Азов (слева) и Кизикермен (справа). Эти крепости непосредственно связаны с Азовскими походами, поэтому здесь всё очевидно. На иконе правая нижняя часть повреждена, а на гравюре Л. Тарасевича мы можем увидеть эти крепости довольно отчетливо (рис. 15).

На гравюре Л. Тарасевича из Киево-Печерского патерика 1702 года чётко видно, что от лапы орла в сторону змия и льва, врагов России, исходят молнии или, как пишет М. Сморжевских, «перуны» (рис. 16). М. Сморжевских, описывая более поздний список иконы, за неимением оригинала, писала: «Руки Петра подняты вверх и перун проходит через правую руку царя (царь, фактически, «низводит» небесный огонь на врагов)». А вот что она пишет о гравюре: «Гравюра Тарасевича во многом повторяет аллегорическую композицию «Азовской Богоматери», но детали изображения здесь уже видоизменены и приспособлены к новым, актуальным для 1702 г. темам: так, перун уже «более не проходит через руку Петра, то есть сюжет низведения царем небесного огня и аналогия с Моисеем утрачены <...> Далее, все перуны (а орел у Тарасевича испускает перуны из обеих лап) направлены на льва: в новой ситуации, когда врагом России стала Швеция, именно лев становится центральным символом, представляющим врага. Всадник со змеем, напротив, оттеснены в левый угол композиции» [16, с. 45]. Необычно то, что на самой иконе эти молнии изображены в виде копья, а на списках иконы они выглядят как на гравюре (рис 17а и 17б). Видимо, иконописцы, когда работали над списками иконы, за неимением прориси ориентировались на гравюру Л. Тарасевича или её письменные описания. 


\section{Культурное наследие - памятники истории и культуры}

DOI: $10.7256 / 2222-1972.2016 .3 .19489$

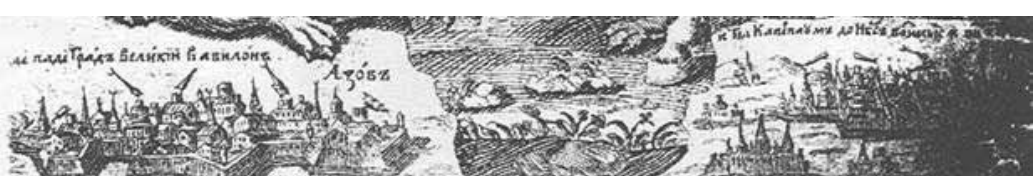

Рис. 15.

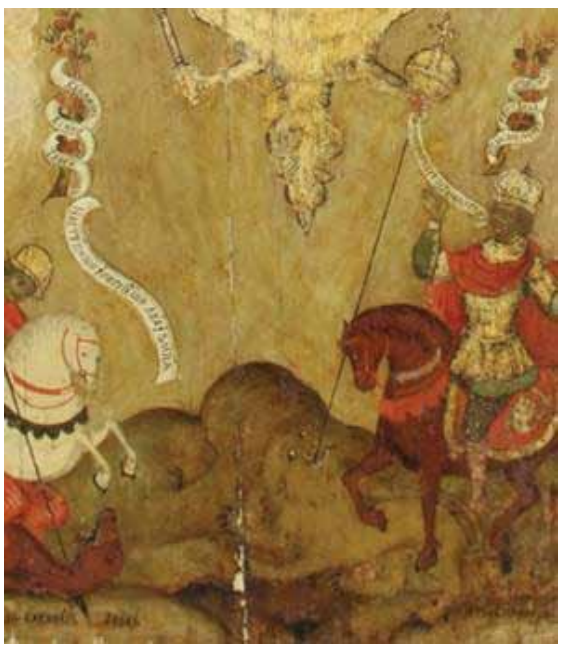

Pис. 17.

\section{4. Значения надписей на иконе}

На иконе имеются надписи, часть которых - это цитаты из Священного Писания или богослужебных книг. Разберемся в их значении.

В центре иконы имеется её название «Знамение множества мира», указывающее на её принадлежность к знаменному типу Богородичных икон, на которых «Богомладенец изображен прямолично на лоне (на груди) Богоматери, представленной по пояс (вариант «Великой Панагии»). В основе иконографии - пророчество о воплощении Спасителя («...Сам Господь даст вам знамение: се, Дева во чреве приимет и родит Сына, и нарекут имя Ему: Еммануил» (Ис 7. 14))»[17].

Самая верхняя надпись, которую мы видим:

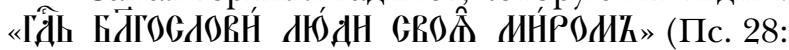
11) (рис. 18).

Эта надпись не требует особого объяснения. Господь благословляет свой народ и это мы видим на иконе.

По обеим сторонам от Господа Саваофа

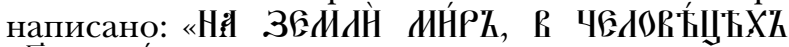

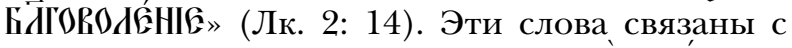

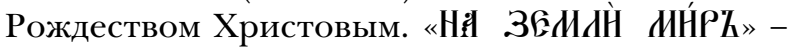
это не только спокойствие на земле, воцарившееся с рождением Христа, но и спасение, «носителем котораго является Новорожденный <...>. Въ человъкахъ благоволеніе» [18, с. 137].

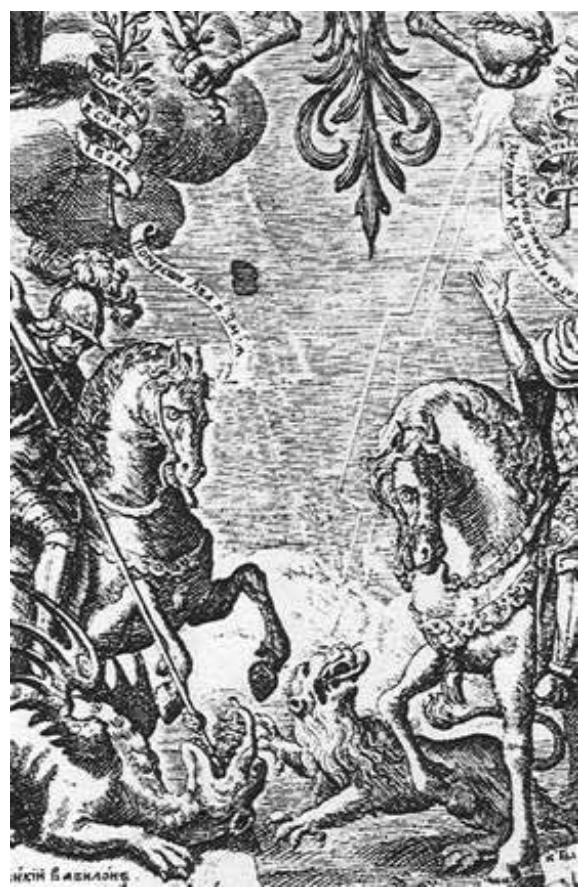

Рис. 16.

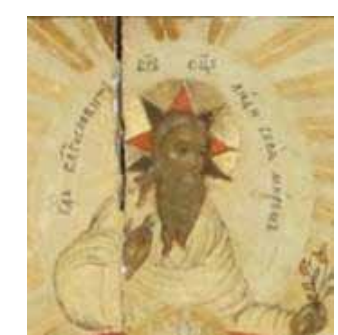

Puc. 18.

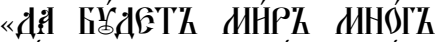

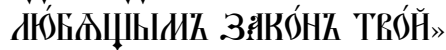

(Пс. 118: 165). Эти цитаты из 2-го Послания св. Апостола Петра и Псалтири не требуют особого комментария ввиду их очевидности.

Под изображением Святого Духа в виде

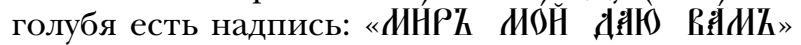
(Ин. 14:27). «Со словами «идите в мире» нередко в Ветхом Завете благочестивые и даже просто люди, знающие приличия, обращались к тем, с кем расставались (1 Цар.1:17, 20:42, 29:7). В обычае такое прощание было и у иудеев во времена Христа (Мк.5:34; Лк. 7:50; Иак. 2:16). И Господь, расставаясь со Своими учениками, прощается обычным образом. Но при этом прибавляет, что в Его устах это приветствие является не простым пожеланием, которое часто и не исполняется, когда его произносят простые люди, а действительным дарованием мира, и притом такого, какой царил в Его собственной душе («мир Мой»). Как Он был владыкой жизни и давал ее кому хотел (ср. Ин. 5:21), так Он является и владетелем 


\section{Исторический журнал: научные исследования № 3 (33) • 2016}

DOI: $10.7256 / 2222-1972.2016 .3 .19489$

мира, который теперь и предоставляет Своим апостолам, как самое нужное для них сокровище. С этим миром им не будет страшно в мире и после удаления Христа» [18, с. 455].

Над изображением Богоматери и двуглаво-

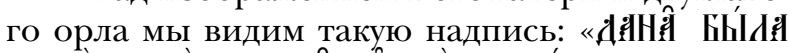

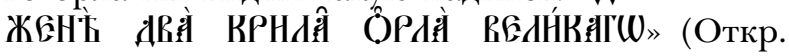
12:14). Господь берет под Своё покровительство «Свою Церковь и даетъ ей два крыла Своего всемогущества и благости» $[19$, с. 565$]$.

По обе руки Богородицы на длинных свитках начертаны благодарственные молитвы Господу и Богородице. Первая из них

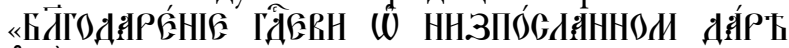
$\hat{\varepsilon} \Gamma\left(\bigcup_{)}\right.$есть несколько изменённая молитва из 2-го Послания св. Апостола Павла к коринфянам (2

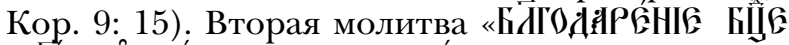

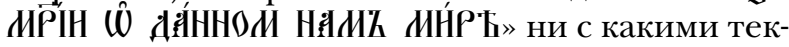
стами Священного Писания или богослужебными текстами в точности не совпадает.

Несколько ниже, с каждой стороны, изображены ветви лавра, перевитые лентами с над-

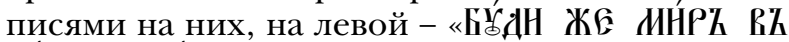
GH́d Т ТRОЕ́Н̆» (Пс. 121: 7), а на правой - «В мире воздержите руци ваши и Благословите Господа». В канонических книгах вторая надпись не встречается. Упоминание этого текста мы находим только в книге В.Д. Бонч-Бруевича, цитирующего неканонический 175-й Псалом [20, с. 168]. Интерпретация этого фрагмента требует дополнительного изучения.

С правой стороны от всадника изобра-

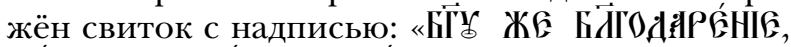

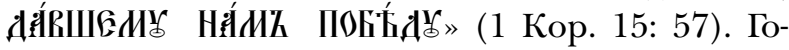
сподь Своим Воскресением победил смерть. «Господь постоянно дает нам силу одерживать побе- ду над грехом» $[11$, с. 125]. Во всём воля Божья, Господь даровал Петру победу над Турцией.

Возле всадника на белом коне тоже есть

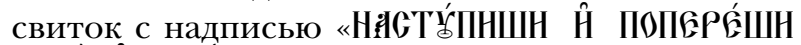

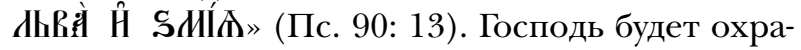
нять праведника от всякого зла и «не причинять ему вреда ни левъ, ни драконъ» [21, с. 313].

В левом нижнем углу над символическим изображением взятой в 1696 году Петром крепости Азов имеется надпись «Паде, паде, великий град Вавилон», взятая из Откровения Иоанна Богослова (Откр. 18: 2). В правом же углу над изображением крепости Кизи-Кермен имеется надпись из Евангелия от Матфея «и ты Капернаумъ до небеси возвысился, низверженъ еси» (Мф. 11: 23).

\section{Выводы}

Основные результаты нашего исследования и его научная новизна состоят в том, что впервые:

1) в научный контекст введён подробный анализ иконографии образа Азовской Божией Матери;

2) в научный искусствоведческий контекст введёно изображение вытегорской иконы, считавшейся безвозвратно утраченной и случайно обнаруженной в краеведческом музее г. Вытегра Вологодской области;

3) осуществлён текстологический анализ надписей, сделанных на исследуемой иконе.

Перспектива дальнейшего исследования: выявить и описать известные списки иконы (как ранние, так и поздние) и осуществить сравнительный анализ их иконографии.

\section{Библиография:}

1. Библия. Священное Писание Ветхого и Нового Завета. Любое издание.

2. Буренкова Е.В. Азовская икона Божией Матери // Православная энциклопедия. Т. 1. М.: Православная энциклопедия, 2008. C. 337.

3. Арутюнов Г.Б. Азов - имя знаменитое. Азов: Инф.-издат. центр «Патарва», 2009. 96 с.

4. Красилин М. М. Памятники искусства XVII - начала XX вв. в немузейных собраниях Москвы. Троицкая церковь на Пятницком кладбище. Каталог-2 // Художественное наследие: хранение, исследование, реставрация: Сб. статей. Вып. 13. М.: Искусство, 1990. С. 127-162.

5. Борин В.М. Два памятника иконографии XVII и XVIII вв.: икона Азовской Божией Матери и прорись с неё // Светильник. 1914. № 8. С. 2-12.

6. Кузык Б.Н. Святая Русь: под Покровом Пресвятой Богородицы. - М.: Институт экономических стратегий, 2009. 632 с.

7. Калашникова Р.Б. Из истории семей заонежских священников (конец 18-первая треть 20 вв.) // Кижский вестник / Редколлегия: И.В.Мельников (отв. ред.), Р.Б.Калашникова, К.Э.Герман. Петрозаводск: Музей-заповедник «Кижи». 2002. № 7. http://kizhi.karelia.ru/library/vestnik-7/275.html.

8. Партанский Спиридон, свящ. Вытегорская Покровская церковь в Вытегорском погосте // Олонецкие губернские ведомости. 1873. № 19.7 марта. С. 8 (212).

9. Церковь Покрова Пресвятой Богородицы (Вытегорский погост) // Википедия. https://ru.wikipedia.org/wiki/ Церковь_ Покрова_Пресвятой_Богородицы_(Вытегорский_погост).

10. Витухновская М.А. Музей-заповедник «Кижи». Петрозаводск: Карелия, 1988.160 с. 


\section{Культурное наследие - памятники истории и культуры}

DOI: $10.7256 / 2222-1972.2016 .3 .19489$

11. Рыбаков А.А. Живопись вытегорского ареала художественной культуры Обонежья XVI-XVIII вв. // Локальные традиции в народной культуре Русского Севера. Мат-лы IV Междун. научн. конф. «Рябининские чтения-2003» / Редкол.: Т.Г.Иванова (отв. ред.) и др. Петрозаводск: Музей-заповедник «Кижи», 2003. http://kizhi.karelia.ru/library/ ryabinin-2003/108.html\# note-id10245508.

12. Петров К. Окрестности города Вытегры // Олонецкие губернские ведомости. 1860. № С. 50-52; № 21 . С. 75-77; № 51. С. 219220 ; № 52. С. 223-224.

13. Петров Константин Михайлович // Энциклопедический словарь. Т. 23. СПб.: Изд. Брокгауза и Ефрона, 1898. С. 462.

14. Лавров А.С. Голицын Василий Васильевич // Большая Российская энциклопедия. Т. 7. М.: БРЭ, 2007. С. $317-318$.

15. Завитухина М.П. Петр І и Сибирская коллекция Кунсткамеры // Из истории петровских коллекций. Сб. научных трудов. Памяти Н.В. Калязиной. СПб: Изд-во Государственного Эрмитажа. 2000. С. 14-26.

16. Погосян Е., Сморжевских М. "Я Деву в солнце зрю стоящу...": образ апокалиптической Жены в русской официальной культуре 1695-1742 гг. // Studia Russica Helsingiensia et Tartuensia. VIII. Tartu: Tartu Ulikooli Kirjastus, 2002. C. 9-37.

17. Сморжевских-Смирнова М. Ингерманландия, Эстляндия и Лифляндия в церковном панегирике Петровской эпохи. Дисс. ... докт. философии. Таллинн: Эстонский гуманитарный институт, Таллиннский университет, 2013. 244 с.

18. «Знамение» // Православная Энциклопедия. Т. 20. М.: Православная Энциклопедия, 2009. С. 271.

19. Лопухин А.П. Толковая Библия или комментарий на все книги Св. Писания Ветхого и Нового Завета. Т. 9. Евангелия от Марка, Луки и Иоанна. СПб.: Странник, 1912. 505 с.

20. Лопухин А.П. Толковая Библия или комментарий на все книги Св. Писания Ветхого и Нового Завета. Т. 11 . Послания Ап. Павла и Откровение св. Иоанна Богослова. СПб.: Странник, 1913. 609 с.

21. Бонч-Бруевич В.Д. Материалы к истории и изучению русского сектантства и раскола. Вып. 2. Животная книга духоборцев. СПб, 1909. XL, 327 с.

22. Лопухин А.П. Толковая Библия или комментарий на все книги Св. Писания Ветхого и Нового Завета. Т. 4. Книга Иова, Псалтирь и Книга притчей Соломоновых. СПб.: Странник, 1907. 502 с.

\section{References (transliterated):}

1. Bibliya. Svyashchennoe Pisanie Vetkhogo i Novogo Zaveta. Lyuboe izdanie.

2. Burenkova E.V. Azovskaya ikona Bozhiei Materi // Pravoslavnaya entsiklopediya. T. 1. M.: Pravoslavnaya entsiklopediya, 2008. S. 337.

3. Arutyunov G.B. Azov - imya znamenitoe. Azov: Inf.-izdat. tsentr «Patarva», 2009. $96 \mathrm{~s}$.

4. Krasilin M. M. Pamyatniki iskusstva XVII - nachala XX vv. v nemuzeinykh sobraniyakh Moskvy. Troitskaya tserkov' na Pyatnitskom kladbishche. Katalog-2 // Khudozhestvennoe nasledie: khranenie, issledovanie, restavratsiya: Sb. statei. Vyp. 13. M.: Iskusstvo, 1990. S. 127-162.

5. Borin V.M. Dva pamyatnika ikonografii XVII i XVIII vv.: ikona Azovskoi Bozhiei Materi i proris' s nee // Svetil'nik. 1914. № 8. S. 2-12.

6. Kuzyk B.N. Svyataya Rus': pod Pokrovom Presvyatoi Bogoroditsy. - M.: Institut ekonomicheskikh strategii, 2009. 632 c.

7. Kalashnikova R.B. Iz istorii semei zaonezhskikh svyashchennikov (konets 18-pervaya tret' 20 vv.) // Kizhskii vestnik / Redkollegiya: I.V.Mel'nikov (otv. red.), R.B.Kalashnikova, K.E.German. Petrozavodsk: Muzei-zapovednik «Kizhi». 2002. http://kizhi.karelia.ru/library/vestnik-7/275.html.

8. Partanskii Spiridon, svyashch. Vytegorskaya Pokrovskaya tserkov' v Vytegorskom pogoste // Olonetskie gubernskie vedomosti. 1873. № 19.7 marta. S. 8 (212).

9. Tserkov' Pokrova Presvyatoi Bogoroditsy (Vytegorskii pogost) // Vikipediya. https://ru.wikipedia.org/wiki/ Tserkov'_Pokrova_ Presvyatoi_Bogoroditsy_(Vytegorskii_pogost).

10. Vitukhnovskaya M.A. Muzei-zapovednik «Kizhi». Petrozavodsk: Kareliya, 1988. 160 s.

11. Rybakov A.A. Zhivopis' vytegorskogo areala khudozhestvennoi kul'tury Obonezh'ya XVI-XVIII vv. // Lokal'nye traditsii v narodnoi kul'ture Russkogo Severa. Mat-ly IV Mezhdun. nauchn. konf. «Ryabininskie chteniya-2003» / Redkol.: T.G.Ivanova (otv. red.) i dr. Petrozavodsk: Muzei-zapovednik «Kizhi», 2003. http://kizhi.karelia.ru/library/ryabinin-2003/108.html\#note-id10245508.

12. Petrov K. Okrestnosti goroda Vytegry // Olonetskie gubernskie vedomosti. 1860. № S. 50-52; № 21. S. 75-77; № 51. S. 219220 ; № 52 . S. 223-224.

13. Petrov Konstantin Mikhailovich // Entsiklopedicheskii slovar'. T. 23. SPb.: Izd. Brokgauza i Efrona, 1898. S. 462.

14. Lavrov A.S. Golitsyn Vasilii Vasil'evich // Bol'shaya Rossiiskaya entsiklopediya. T. 7. M.: BRE, 2007. S. 317-318.

15. Zavitukhina M.P. Petr I i Sibirskaya kollektsiya Kunstkamery // Iz istorii petrovskikh kollektsii. Sb. nauchnykh trudov. Pamyati N.V. Kalyazinoi. SPb: Izd-vo Gosudarstvennogo Ermitazha. 2000. S. 14-26.

16. Pogosyan E., Smorzhevskikh M. "Ya Devu v solntse zryu stoyashchu...": obraz apokalipticheskoi Zheny v russkoi ofitsial'noi kul'ture 1695-1742 gg. // Studia Russica Helsingiensia et Tartuensia. VIII. Tartu: Tartu Ulikooli Kirjastus, 2002. S. 9-37.

17. Smorzhevskikh-Smirnova M. Ingermanlandiya, Estlyandiya i Liflyandiya v tserkovnom panegirike Petrovskoi epokhi. Diss. ... dokt. filosofii. Tallinn: Estonskii gumanitarnyi institut, Tallinnskii universitet, 2013.244 s.

18. «Znamenie» // Pravoslavnaya Entsiklopediya. T. 20. M.: Pravoslavnaya Entsiklopediya, 2009. S. 271.

19. Lopukhin A.P. Tolkovaya Bibliya ili kommentarii na vse knigi Sv. Pisaniya Vetkhogo i Novogo Zaveta. T. 9. Evangeliya ot Marka, Luki i Ioanna. SPb.: Strannik, 1912. 505 s.

20. Lopukhin A.P. Tolkovaya Bibliya ili kommentarii na vse knigi Sv. Pisaniya Vetkhogo i Novogo Zaveta. T. 11. Poslaniya Ap. Pavla i Otkrovenie sv. Ioanna Bogoslova. SPb.: Strannik, 1913. 609 s.

21. Bonch-Bruevich V.D. Materialy k istorii i izucheniyu russkogo sektantstva i raskola. Vyp. 2. Zhivotnaya kniga dukhobortsev. SPb, 1909. XL, $327 \mathrm{~s}$.

22. Lopukhin A.P. Tolkovaya Bibliya ili kommentarii na vse knigi Sv. Pisaniya Vetkhogo i Novogo Zaveta. T. 4. Kniga Iova, Psaltir' i Kniga pritchei Solomonovykh. SPb.: Strannik, 1907. 502 s. 